\title{
Assessing the Impact on Social Sector: A Macroeconomic Approach
}

\author{
K.V. Bagmet \\ $\mathrm{PhD}$ in Economics, Sumy State University, Ukraine
}

Olena Haponova

PhD Student, Department of Finance and Entrepreneurship, Sumy State University, Ukraine

\begin{abstract}
This paper summarizes the arguments and counterarguments within the scientific discussion on the issue of the institutional quality of the social sector, its measurement, and the impact of institutional transformations on the creation of positive social results. The main purpose of the research is to present an empirical study of the relationship between the quality of social sector institutions and the parameters of social and economic development, social activity and trust, subjectively evaluated by individuals. The evaluation of macro impact (positive social results at the macrolevel) were evaluated based on three components: health, wellbeing, and political engagement. The findings showed a direct significant relationship between the quality of social institutions on the one hand and health and well-being on the other. The obtained results do not allow to substantiate enough the connection between the quality of social institutions and social confidence and involvement in political life without conducting additional research. However, the level of social confidence and the desire to participate in public and political life directly depends on the level of economic development of the country (GDP per capita).
\end{abstract}

The analysis was carried out for 11 countries (Austria, Belgium, the Czech Republic, Germany, Estonia, Finland, France, the United Kingdom, the Netherlands, Poland, Sweden). For the countries under consideration, it can be stated that the social sector creates social value, significant, long-term changes in people's lives are conditioned by the development of institutions, their quality. So, governments that are now choosing a social sector model need to focus their efforts primarily on creating quality institutions. At the same time, they should focus their efforts on the collection of reliable data, allowing for a deeper analysis of the social sector development, to improve on this basis the methodology for assessing social impact, especially at the macroeconomic level.

Keywords: impact, social sector, institutions, assessment, health, well-being, political engagement.

JEL Classification: O10, C38.

(C) The Author, 2018. This article is published with open access at Sumy State University.

\section{Introduction}

The issue of assessing social impact has attracted increasingly greater attention. The informative nature of social results, their influence on the decision-making on financing a social project are becoming increasingly important for philanthropists, foundations, and other charitable organizations. Now the cost of impact assessment is about $10 \%$ of the project budget on average. Moreover, the share of expenses for the evaluation in the overall project budget is not stable - for large funds it is usually less than for small funds. There is a trend towards an increase in the number of charitable foundations and organizations that increase the amount of expenditure for impact assessment [14].

After the financial crisis of 2008-2009 the development of impact investment has been updated. Now, the convergence of the investment market for influence and major capital markets is noted [10]. This is manifested in an increase in the number of investors wishing to include investment of influence in their portfolios. However, a full-fledged practice of including investment impact can be said when the methods of impact assessment will be integrated into traditional investment decision-making procedures, as well as an expanded classification of investments, that is, clear criteria for distinguishing investment impact and other types of investments are formed. Standardized, reliable, substantial, comparable data will allow to develop the mechanisms for reducing the risks associated with investment impact. The solution of these issues lies in the development of the methodology for measuring and assessing the impact of a particular project, specific activity. 
Another important issue is the economic evaluation of the impact of the non-profit sector on the national economy as a whole, as these assessments allow the creation of a database to identify areas for which to work in order to improve the functioning of the third sector itself, as well as to understand the impact of the latter aggregated social value or even economic performance, which creates a social sector in the macroeconomic dimension.

The development of a methodology for assessing social impact for both micro- and macro-levels is a big challenge. By measuring the influence of the organization (microlevel), discussions so far lead to diametrically opposed recommendations - from the need to provide clear quantitative estimates of social impact, to the justification for failing to provide such assessments, because activities in the social sector are to some extent unique or too context-dependent, evaluation framework.

Adequate assessment of the impact on the macroeconomic level is complicated by the place of the social sector in the country's economy. Many factors affect the scale of the social sector. These include state policy and policy at the interstate level, the development of capital markets, the modification of regulatory approaches, the emergence of new spheres in the economy, the development of networks for cooperation, and the like. Similarly, the social sector (in its broad sense) has an impact on the national economy, creating social value. In our opinion, the root of social value in the aggregate dimension (macroscale measurement) lies in the functioning of institutions. On the one hand, the activity of organizations in the third sector, the social economy depends on the level of development of institutions, their quality, and on the other hand, the social sector, producing social effects (social cohesion, democratic decision-making, civil society, etc.) in the modern world makes a significant impact on institutional changes. Moreover, there are changes in both social, political and financial institutions, new market mechanisms are being formed, working on the implementation of social needs (social end development impact bonds, Impact Reporting and Investing Standards, etc.). Today, a thorough aggregate analysis of this aspect of social sector development is complicated by the lack of analysis of sectoral indicators. In particular, the lack of participation of institutional investors (pension funds, banks, etc.) in social investment is explained by the lack of benchmarking and rating assessments. Thus, according to Monitor Institute estimates, the volume of investments in social and environmental impact for 10 years could grow to 500 billion dollars USA (starting from 2008). The process of creating non-profit rating agencies began to provide their assessments, Charity Navigator, Better Business Bureauєs Wise Giving Alliance, which in late 2009 started developing a package of complex activities (not only financial, but also social) [10].

So, through the development of an assessment of the aggregate social sector impact on the economy of the country, the principles and procedures for regulating the development of the social sector at the state and global levels can be improved, and the development of market institutions will be promoted.

\section{Literature review}

The presented studies concern the development of measurement and impact assessment at the level of nonprofit organizations $[8 ; 9 ; 13]$, the improvement of their management $[11 ; 12]$, which are of interest primarily to the managers of these organizations, since they can create the basis for decision-making and improve management.

Some studies are aimed at the development of long-term assessments. There are proposed evaluations of the effectiveness of the strategy in addition to estimates of "visible" outputs and outcomes $[10 ; 14 ; 15]$. The strategic aspects of evaluation include focusing on the impact. However, the question arises about the advisability of its evaluation, since it is rather difficult to measure.

Several projects aimed at developing approaches to assessing social influence in the macroeconomic dimension have been implemented in the European Union [1,2].

Bernard Enjolras (2016) proposed a macro impact explanatory model in which he described the mechanism of the impact of institutional changes in the social sector caused by the involvement of a wide range of individuals in the social services sector (the third sector). The author found that the development of this sector, estimated with the help of the share of the workforce involved in it, has a significant connection with the selected macroeconomic impact (social trust, political engagement, self-reported wellbeing and self-reported health) [3].

\section{Methods}


The presence of a direct link between the level of development of institutions and macroeconomic results at the country level is now a proven fact. Indeed, today economically developed countries are the countries that are characterized by the high quality of domestic institutions, such as the protection of property rights, the fight against corruption, compliance with laws, access to participation in socio-political and economic life. The high quality of institutions also directly affects the indicators of well-being, health, trust in society and the like (Figure 1).

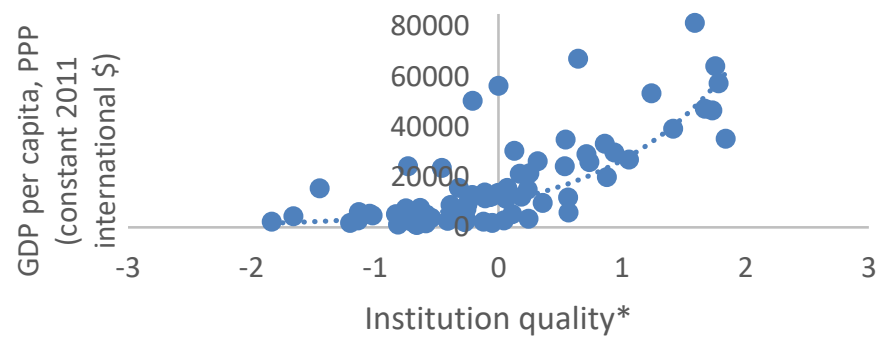

Figure 1. The dependence between the quality (development) of institutions and the economic results of countries (determined by The Worldwide Governance Indicators, [16])

The development of institutions for developing countries is even more relevant in the context of achieving economic progress. So, according to IMF estimates, if the quality of institutions in African countries could be raised to the level of Asian developing countries, then one would expect GDP growth per capita to be almost double [17].

The question is to what extent institutional transformations contribute to the growth of positive social effects such as higher levels of trust, health, well-being or political engagement at the individual level, are also of scientific interest.

In our research, we set the task to confirm empirically the existence of a link between the quality of institutions of the social sector and the parameters of social and economic development, social activity and trust, subjectively assessed by the individual. It should be noted that within the framework of this work there will be no comprehensive answers to the questions raised, which is due to the complexity of identifying the whole complex of cause and effect implications in the processes of institutional transformations, as well as problems with the availability of statistical data for the assessment of impacts. The allocated indicators will only allow the first approximation to assess the current impact of the social sector on the economy and society, and it is possible to achieve progress in the regulation of the social sector.

In the impact assessment, we are guided by its definition as "significant or prolonged changes in people's lives caused by a certain activity or series of actions" [10, p. 3], therefore, we use political engagement, self-reported wellbeing and self-reported health as Indicators of Macro Impact. The analysis is based on data from 11 countries (Austria, Belgium, the Czech Republic, Germany, Estonia, Finland, France, the United Kingdom, the Netherlands, Poland, Sweden), as dependent variables we will use the data obtained in the process of implementing the European Social Survey (ESS) project. This is an academically driven cross-national survey that has been conducted across Europe since its establishment in 2001. Data collection for ESS in all countries is conducted according to a standard methodology for all, by mass interviewing using personal interviews of respondents [7]. Ukraine was not factor in this survey, so we are not able to conduct comparable calculations for this country.

As indicators of macroimpacts, we use indicators calculated as the sum of percent of respondents who gave positive answers to the following questions:

self-reported health - How is your health in general? (Sum of Categories: 1 Very good, 2 Good, 3 Fair of 9); self-reported wellbeing - How happy are you? (Sum of Categories: 10 (Extremely happy), 9 (no name), 8 (no name) of 10);

social trust and political engagement - Political system allows people to have influence on politics? (Sum of Categories: 10 (Completely), 9 (no name), 8 (no name) of 10). 
For further crosscountry analysis, comparison and data processing, the output results were normalized to account for differences in the number of respondents and the number of people in countries. Thus, the population size weight makes an adjustment to ensure that each country is represented in proportion to its population size.

The quality of social institutions is assessed using the Social Sector Institutional Quality Index (SSIQI) [4].

\section{Results}

In the process of specification of the model, we estimated the existence of a correlation between the index of the institutional quality of the social sphere, as an independent variable, and the three selected macro impacts, as dependent variables (Appendix A). The calculated values of correlation coefficients between variables are for Self-reported health -0.6396 ; Self-reported wellbeing -0.3774 ; Social trust and political engagement 0.3776 . So, according to the results of the preliminary analysis, there is a stable direct relationship between the institutional quality and three impacts analyzed.

To prevent the loss of significant variables and, therefore, the growth of the problem of endogenity, we introduced into the model the values of GDP per capita converted to international dollars using purchasing power parity rates and the Human Development Index, as additional variables that can influence the impacted impulse. To obtain better estimates, we used all the variables in the model in the form of a logarithm.

So the general list of variables in the model is presented in Table 1. The expediency of introducing these variables into the model is confirmed by high values of the correlation coefficients.

Table 1. The list of variables for constructing the regression

\begin{tabular}{|l|l|l|}
\hline \multicolumn{1}{|c|}{ Variables } & \multicolumn{1}{|c|}{ Indicator } & \multicolumn{1}{c|}{ Abbreviation } \\
\hline Dependent 1. Social trust and political engagement & $\begin{array}{l}\text { European Social Survey, Political system allows } \\
\text { people to have influence on politics? }\end{array}$ & Y1politic \\
\hline Dependent 2. Self-reported health & $\begin{array}{l}\text { European Social Survey, How is your health in } \\
\text { general? }\end{array}$ & Y2health \\
\hline Dependent 3. Self-reported wellbeing & European Social Survey, How happy are you? & Y3Happy \\
\hline Independent 1. Gross domestic product & $\begin{array}{l}\text { World Bank, GDP, PPP (constant 2011 interna- } \\
\text { tional \$) }\end{array}$ & X1GDP \\
\hline Independent 2. Human development & World Bank, Human Developmet Index & X2HDI \\
\hline Independent 2. Quality of institutions & $\begin{array}{l}\text { Author's Social Sector Institutional Quality Index } \\
\text { (SSIQI)* X3Index }\end{array}$ \\
\hline
\end{tabular}

The results of the linear regression of the three macro impacts when considering interaction with the quality of social institutions and additional control variables are presented in the following three tables.

Table 2. The parameters of linear regression of social trust and political engagement

\begin{tabular}{|l|c|c|c|c|}
\hline & Coef. & Std. Err. & t & p-value \\
\hline Constant & $-0,53417$ & 28,20592 & $-0,018938219$ & 0,9854189 \\
\hline X1GDP & $-0,12851$ & 2,398998 & $-0,053569115$ & 0,9587752 \\
\hline X2HDI & 1,660277 & 2,299392 & 0,722050439 & 0,4936719 \\
\hline X3Index & 12,99344 & 20,48555 & 0,634273757 & 0,5460636 \\
\hline R-squared & 0,316944 & & & \\
\hline
\end{tabular}

The obtained results do not allow to substantiate with sufficient justification the relationship between the quality of social institutions and Social trust and political engagement without conducting additional research. The value of the coefficient of determination shows that the model makes it possible to explain about $32 \%$ of the variability. However, in the first approximation, we can argue that the level of social confidence and the desire to participate in public and political life directly depends on the level of economic development of the state. The coefficients for the remaining variables should be ignored, because the p-value threshold is exceeded.

Table 3. Linear regression parameters of Self-reported health

\begin{tabular}{|l|c|c|c|c|}
\hline & Coef. & Std. Err. & t & p-value \\
\hline Constant & 6,957075 & 5,173076 & 1,344862485 & 0,2206102 \\
\hline X1GDP & $-0,0441$ & 0,439986 & $-0,100235856$ & 0,9229675 \\
\hline X2HDI & $-0,99904$ & 0,421718 & $-2,368983992$ & 0,0496804 \\
\hline X3Index & 7,259412 & 3,75713 & 1,932169727 & 0,0946196 \\
\hline R-squared & 0,733563 & & & \\
\hline
\end{tabular}


$\mathrm{R}$-squared regression of Self-reported health indicates a high quality model. The proposed independent variables describe $73 \%$ of the variance of the dependent variable. P-value characterizes the statistical significance and allows to reject the null hypothesis for two variables. The coefficients indicated in the table are the values of the vase logarithm and therefore do not have a physical definition. Exhibiting the indicators and analyzing the values obtained allows us to conclude that people positively assess the state of their health in countries with high standards of quality of life indicators, education and other factors characterizing the development of human capital. One of the main factors conditioning this situation is the quality of social institutions. Thus, the growth of their quality will have a positive impact on improving people's health. Also interesting is the fact that assessing individuals about their own health does not depend on the size of the country's GDP.

Table 4. Linear Regression Parameters of Self-reported wellbeing

\begin{tabular}{|l|c|c|c|c|}
\hline & Coef. & Std. Err. & t & p-value \\
\hline Constant & 11,29206 & 7,76973 & 1,45333956 & 0,1894434 \\
\hline X1GDP & $-0,50393$ & 0,660839 & $-0,762554677$ & 0,4706392 \\
\hline X2HDI & $-0,58102$ & 0,633401 & $-0,917302978$ & 0,3894942 \\
\hline X3Index & 11,64754 & 5,643042 & 2,064053008 & 0,0778976 \\
\hline R-squared & 0,603225 & & & \\
\hline
\end{tabular}

The last regression testifies the growing role of the quality of social institutions in evaluating their own wellbeing, only this independent variable demonstrates statistical significance. Such conclusions are explained by the results of the survey of the World Values Survey, where the percentage of very lucky and lucky people is approximately the same for countries that are fundamentally different in terms of economic development indicators (Table 5).

Table 5. Feeling of Happiness by World Values Survey Wave 6: 2010-2014 [6]

\begin{tabular}{|l|c|c|c|c|c|c|c|c|}
\hline & Germany & Libya & $\begin{array}{c}\text { New } \\
\text { Zealand }\end{array}$ & Pakistan & Qatar & Zimbabwe & $\begin{array}{c}\text { Trinidad and } \\
\text { Tobago }\end{array}$ & $\begin{array}{c}\text { United } \\
\text { States }\end{array}$ \\
\hline Very happy & 23,1 & 38,5 & 33,7 & 45,6 & 56,4 & 39,4 & 54,2 & 36,1 \\
\hline Rather happy & 60,9 & 49 & 58,7 & 39,1 & 41,6 & 39,5 & 33,8 & 53,5 \\
\hline $\begin{array}{l}\text { Not very } \\
\text { happy }\end{array}$ & 13,4 & 8,7 & 4,3 & 10,9 & 1,7 & 18,7 & 11,1 & 8,8 \\
\hline $\begin{array}{l}\text { Not at all } \\
\text { happy }\end{array}$ & 1,5 & 2,9 & 0,7 & 4,2 & 0,3 & 2,5 & 0,9 & 1,2 \\
\hline No answer & 0,2 & 0,2 & 1,8 & 0,2 & 0 & 0 & 0 & 0,5 \\
\hline Don't know & 1 & 0,7 & 0,8 & 0 & 0 & 0 & 0 & 0 \\
\hline (N) & 2,046 & 2,131 & 841 & 1,2 & 1,06 & 1,499 & 999 & 2,232 \\
\hline
\end{tabular}

\section{Conclusions and Discussion}

Assessments of the impact of the social sector, conducted on the basis of three components: health, wellbeing and political engagement, showed a direct significant relationship between the quality of social sector institutions, health and wellbeing. That is, in the countries for which the analysis is carried out, the social sector creates social value. Political engagement impact on the contrary does not depend on the development of the social sphere, but demonstrates the dependence on the size of the country's GDP. So, governments which do not choose a social sector model need to focus their efforts on creating quality institutions.

We understand that the conducted assessments do not give a picture of the impact of the social sector on the economy. There remain many issues requiring research such as the development of the capital market in the context of intensifying impact investment and the development of new financial instruments, the growth of the scale of social entrepreneurship and the role of the social economy as a whole. However, a statistically established relationship between social sector institutions and aggregated impacts gives grounds for further research on this topical issue. It is important to realize that further progress in this depends on a number of factors, the main one of which we consider the quality of the data. The information component occupies a central place in the system of interaction of various stakeholders - it provides the basis for decision-making, gives grounds for compensation, affects the redistribution of resources and the like. Given such a place and the role of information support, a certain regulatory framework should be formed. Its purpose is primarily to include as many participants as possible due to the use of common rules and approaches. The collection of reliable data, appropriate reporting will allow for a more in-depth analysis of the development of the social sector, improve on this basis the impact assessment methodology, especially at the macroeconomic level. Therefore, the process of regulating institutional changes may include the development of evaluation standards. 


\section{References}

1. Anheier, H. K., Krlev, G., Preuss, S., Mildenberger, G., Einarsson, T. (2014). Theory and empirical capturing of the third sector at the macro level. Deliverable 2.1 of the project: 'Impact of the Third sector as Social Innovation' (ITSSOIN), European Commission - 7th Framework Programme, Brussels: European Commission, DG Research.

2. Bernard Enjolras (2016) Assessing the macro socioeconomic impact of the third sector in Europe. Theoretical considerations and some empirical evidences TSI Working Paper Series No. 10. Seventh Framework Programme (grant agreement 613034), European Union. Brussels: Third Sector Impact. Retrieved from: http://thirdsectorimpact.eu/documentation/tsi-working-paper-no-10-assessing-macro-socio-economic-impact-third-sector-europe/.

3. Daniel Kaufmann, Aart Kraay and Massimo Mastruzzi (2010). The Worldwide Governance Indicators: A Summary of Methodology, Data and Analytical Issues. World Bank Policy Research Working Paper No. 5430. Retrieved from: http://papers.ssrn.com/sol3/papers.cfm?abstract id=1682130.

4. Data \& Documentation. World Values Survey. Retrieved from: .http://www.worldvaluessurvey.org/WVSOnline.jsp.

5. Data and Documentation. European Social Survey. Retrieved from: http://www.europeansocialsurvey.org/data/.

6. Ebrahim, A., \& Rangan, V. K. (2010). The limits of nonprofit impact. Harvard Business Review Online. Retrieved from http.//evpa.eu.com/wpcontent/uploads/2011/06/measuring.pdf.

7. Epstein, M. J. and Yuthas, K. (2014). Measuring and improving social impacts - a guide for nonprofits, companies and impact investors. Greenleaf Publishing, Sheffield. Retrieved from: https://ssir.org/articles/entry/measuring_and_improving_social_impacts_a_guide_for_nonprofits_companies_and.

8. Fay Twersky, Amy Arbreton (2014). Benchmarks for Spending on Evaluation. The William And Flora Hewlett Foundation. Retrieved from: https://www.hewlett.org/wp-content/uploads/2016/08/Benchmarks\%20for\%20Spending\%20on\%20Evaluation_2014.pdf.

9. Hadad, S., Găucă, O. (2014). Social impact measurement in social entrepreneurial organizations. Management \& Marketing. Challenges for the Knowledge Society, 9(2), 119-136. Retrieved: http://www.managementmarketing.ro/pdf/articole/445.pdf.

10. Hehenberger, L., Harling, A-M., and Schölten, P. (2013). A practical guide to measuring and managing impact. Brussels: European Venture Philanthropy Association, 124. Retrieved from: http://evpa.eu.com/publication/guide-measuring-and- managing-impact-2015/.

11. Marc J. Epstein \& Kristi Yuthas (2014). Measuring and Improving Social Impacts: A Guide for Nonprofits, Companies, and Impact Investors. Retrieved from: https://ssir.org/articles/entry/measuring_and_improving_social_impacts_a_guide_for_nonprofits_companies_and.

12. Review of foreign experience in assessment, incl. in the field of child protection [Obzor zarubezhnogo opyta po otsenke, v t.ch. v sfere zashchity detstva]. Retrieved from: https://www.slideshare.net/evd_oa/ss76491009.

13. So I. (2015). Measuring the "impact" in impact investing. Ivy So \& Alina Staskevicius, MBA, Harvard Business School. Retrieved from: http://www.hbs.edu/socialenterprise/Documents/MeasuringImpact.pdf.

14. The Worldwide Governance Indicators (WGI) project. Worldwide Governance Indicators. Retrieved from: http://info.worldbank.org/governance/wgi/index.aspx\#home.

15. Vasilyeva, T., Lyeonov, S., Adamičková, I., Bagmet, K. (2018). Institutional Guality of Social Sector: the Essence and Measurements. Economics and Sociology, 11(2), 21-32. doi:10.14254/2071-789X.2018/112/17.

16. World Economic and Financial Surveys. World Economic Outlook, Building Institutions (September 2005). International Monetary Fund. Retrieved from: http://www.imf.org/external/pubs/ft/weo/2005/02/. 